\title{
ÚTÉPÍTÉSBEN HASZNÁLT KŐANYAGOK LEHETSÉGES ANYAGVIZSGÁLATI MÓDSZEREI
}

\author{
Géber Róbert \\ egyetemi docens, Miskolci Egyetem, Kerámia- és Polimermérnöki Intézet \\ 3515 Miskolc, Miskolc-Egyetemváros, e-mail: robert.geber@uni-miskolc.hu
}

\begin{abstract}
Absztrakt
Jelen cikk különbözö, az anyagtudományban alkalmazott anyagvizsgálati módokat ismertet, fókuszálva azok aszfalttechnológiai alkalmazhatóságára. A technikák bemutatásával a Szerzö célja az aszfaltgyártók érdeklödésének felkeltése, annak érdekében, hogy köanyagokról pontosabb ismeretek váljanak elérhetövé. Az igy szerzett ismeretek segithetik az aszfaltechnológusok munkáját a gyártástechnológia során.
\end{abstract}

Kulcsszavak: anyagvizsgálat, aszfalt, köanyag, töltöanyag

\begin{abstract}
This article presents different testing methods used in materials science, focusing on their applicability in asphalt technology. By presenting these techniques, the Author aims to arouse the interest of asphalt manufacturers in order to make more accurate knowledge about mineral materials available. The knowledge gained in this way can support the work of asphalt technologists in manufacturing technology.
\end{abstract}

Keywords: asphalt, filler, materials testing, mineral aggregate

\section{Bevezetés}

Az aszfaltok szemcsés ásványi anyagok és bitumen kötőanyag kombinációjából állnak. A kompozit anyagrendszer ásványi vázát különböző szemcseméretü kőzetek alkotják. Az aszfaltburkolatok maximális teherbíró képessége a bitumennel kevert, precízen beállított szemcseeloszlású ásványi anyagok és tömörítési technológia alkalmazásával érhető el [1].

Aszfaltkeverékek ásványi kőanyagaiként legelterjedtebben karbonátos (mészkő) és vulkáni eredetủ kiömlési magmás (andezit, bazalt) kőzeteket használnak. Ezek az anyagok jó kőzetfizikai tulajdonságaik mellett a bitumenhez is képesek jól kötődni. Szemcseméretük szerint megkülönböztetünk zúzottkövet, homokot, illetve töltőanyagot, melyeket a forgalmi igénybevételeknek megfelelő arányban adagolva használnak fel. A töltőanyag $(\mathrm{d}<0,063 \mathrm{~mm})$, mint az ásványi váz legfinomabb frakciójának szemcseméret-eloszlása aszfalttechnológiai szempontból kiemelt jelentőséggel bír [2]. Morfológiája, szemcsemérete és polidiszperzitása, térkitöltése a bitumen viszkozitását, ezáltal a burkolat merevségét, és bedolgozhatóságát is nagymértékben befolyásolja $[3,4,5,6]$. A finomrész jelenléte pedig - felületi sajátosságai miatt - a kötőanyag adszorpciós képességére is hatással van [7].

A töltőanyagok aszfaltkeverékekben betöltött szerepének tanulmányozásával számos kutató foglalkozott. Grabowski és Wilanowicz [4] munkájukban kvantitatív összefüggéseket kerestek mészkőlisztek egyes jellemzőinek (szemcseméret-eloszlás, fajlagos felület, a szemcsék közötti ún. Rigdenhézagtérfogat, gömbszerüség, felületi textúra) és ezeknek a töltőanyagoknak a bitument merevítő tu- 
lajdonságai között. Eredményeik alapján jelentős különbségeket tapasztaltak a töltőanyagok szerkezete és a vizsgált jellemzők tekintetében. Ishai és Craus [6] a térkitöltési elméletet felhasználva számos kísérletet végzett el különböző ásványi anyagokon. A fajlagos felületi érdességet, mint a térkitöltés egy fontos jellemzőjét olyan paraméternek írták le, amely az ásványi anyagok geometriai rendellenességét jól jellemzi, végső soron befolyásolja az aszfaltkeverékek tulajdonságait.

Shashidar és munkatársai $[8,9]$ munkáikban szemcsés ásványi anyagok aszfaltkeverékek reológiai tulajdonságait befolyásoló hatásait vizsgálták. Véleményük szerint a szemcsék közötti interakció, a szemcsék agglomerálódása, a szemcsék alakja és elhelyezkedése csökkenti a térkitöltést. Mindezek hatással bírnak az aszfaltkeverékek merevségére.

Liao és társai [10] ásványi töltőanyagok aszfalthabarcsban és aszfaltkeverékekben betöltött szerepét vizsgálták a merevítő hatás és a tönkremenetel tekintetében. Eredményeik azt mutatták, hogy a töltőanyagok mennyisége szignifikánsan befolyásolja az aszfalthabarcsok merevségét; a nagy mennyiségü töltőanyag pedig rendkívül gyorsan megnöveli a habarcs merevségét. A hazai kutatási eredmények szempontjából kiemelkedőek a Tóth és társai által elvégzett kutatások [11-13] is, melyek elsősorban az aszfaltkeverékek merevségének és fáradási jellemzőinek vizsgálataira irányultak. Eredményeik elősegítették a hazai aszfaltkeverékek reológiai viselkedésének pontosabb megértését.

A fentiek alapján könnyen belátható, hogy a jó minőségủ, hosszú élettartamú aszfalt teljesítményét - a megfelelő gyártási és beépítési technológia mellett - az ásványi anyagok minősége és tulajdonságai is alapvetően befolyásolják.

A Miskolci Egyetem Kerámia- és Polimermérnöki Intézetében - és annak jogelődjében - immár 15 éve végeznek aszfaltipari kutatásokat. A kutatások az aszfaltkeverékekben felhasznált ásványi anyagok tulajdonságainak feltárására [14-16], reológiai tulajdonságokra [17-20], illetve potenciális másodlagos nyersanyagok alkalmazhatóságának vizsgálatára fókuszálnak [21-23]. A kutatási eredmények az aszfalttechnológiában nem alkalmazott méréstechnikai módszereknek köszönhetően - hozzájárulnak az aszfalttechnológusok, illetve a kőanyag beszállítók ismereteinek bővítéséhez is. Jelen cikk célja, hogy egy olyan áttekintést mutasson be azokról a vizsgálati módszerekről és technikákról, amelyek kiegészíthetik az aszfaltok és alapanyagaik minősítési gyakorlatát.

\section{Helyzetértékelés}

Az aszfaltgyártási technológiához kapcsolódó vizsgálati módszereket a kapcsolódó szabványok, illetve Útügyi Müszaki Elöírások rögzítik. Ezek egyaránt kitérnek az alapanyagok (ásványi anyagok, illetve kötőanyagok), valamint a bekevert és beépített aszfalt jellemzőinek vizsgálataira. Ugyanakkor a méréstechnikai módszerek rohamos fejlődésével egyre nagyobb teret kapnak a különböző anyagvizsgálati módszerek.

A következőkben bemutatásra kerülő anyagvizsgálati módszerek az anyagtudományi kutatásokban már elterjedtek, ugyanakkor alkalmazásuk az aszfalttechnológiai gyakorlatban - nemzetközi viszonylatban is - még meglehetősen szük körü.

A különböző - roncsolásos és roncsolásmentes - anyagvizsgálati módszerek tárgyalása az ásványi anyagok aszfaltkeverékben betöltött szerepe alapján kerül bemutatásra. Jelen cikkben a kőzetek jól ismert minősítési módjai (pl. kőzetfizikai osztályozás) nem kerülnek ismertetésre.

Ha sorra vesszük azokat a legfontosabb tulajdonságokat, amelyekkel az ásványi anyagok jellemezhetők, első helyen az összetétel szerepel. Ismert, hogy az ásványi anyagok összetételét a kőzetképzödési körülmények alapvetően meghatározzák. Ebből adódóan az ásványi anyagok összetétele lelőhelyenként és a kőbányák munkaszintjeiként is változik. Amennyiben a kőanyag agyagásványokban dús, 
úgy mechanikai szilárdsága csökken, a forgalom hatására pedig könnyebben aprózódhat, amely a burkolat tervezettnél korábbi tönkremenetelét eredményezheti.

A beépített aszfaltburkolat szilárdságát az ásványi kőváz megfelelő granulometrikus összetétele is biztosítja. Mivel a szemeloszlás az aszfaltkeveréken belül a durva szemcséktől a finom szemcsékig változik, így a kőváz tulajdonképpen egy polidiszperz rendszerként írható le. A durva frakciók szemeloszlása hagyományosan szitaanalízis segítségével határozható meg, míg a legkisebb szemcsék menynyiségének és megoszlásának vizsgálatára a hidrometrálást alkalmazzák az útépítési gyakorlatban. Ennek a módszernek azonban nagy hátránya a hosszú vizsgálati idő.

A kőanyagok szemalakjának szempontjából az érdesebb felületü és szögletes szemek felhasználása célszerü, mivel ezek a szemek az ásványi váz belső súrlódását növelik, ez pedig a burkolat szilárdságának növekedését eredményezi. A durva frakciók (zúzott kövek) esetén a szemalak vizsgálatához speciális szemalak tolómérőt használnak a gyakorlatban. Ugyanakkor a töltőanyag frakció esetén a szemalak vizsgálatára hagyományosan nincs mód, ez csupán mikroszkópi úton valósítható meg.

Fontos megemlíteni, hogy a töltőanyagok az alábbi folyamatokat befolyásolják: a bitumen kővázhoz történő tapadását, az aszfalt bedolgozhatóságát (tömöríthetőségét), a vízérzékenységet, az aszfalt öregedését, valamint az aszfaltburkolat nyomvályúsodással szembeni ellenállását.

A felhasznált ásványi anyagok szemalakjának emellett van egy másik fontos hatása is. A töltöanyagot bitumennel keverve kialakul az ún. aszfalthabarcs, amely erösebb kötést képes kialakítani, mint önmagában a bitumen. Az aszfalthabarcs viszkozitásának változását a szemcse alakjának függvényében az 1. ábra szemlélteti.

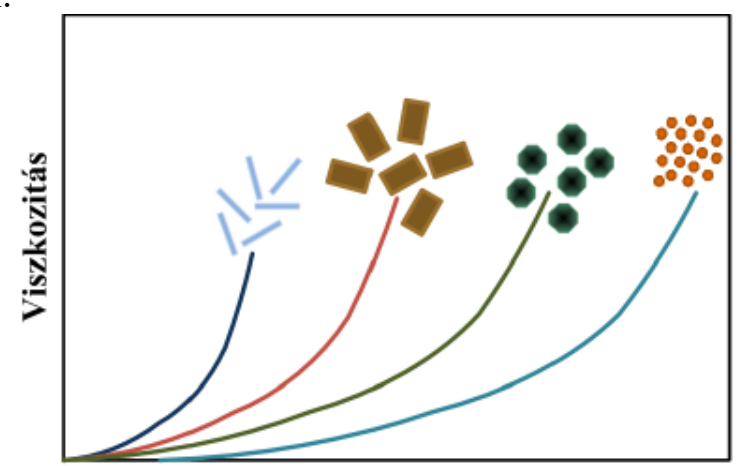

A szemcsék térfogataránya

1. ábra. A szemalak hatása az aszfalthabarcs viszkozitására [24].

Az 1. ábra alapján tehát belátható, hogy a szemcsék geometriai sajátosságainak, morfológiájának is meghatározó szerepe van az aszfalthabarcs folyási tulajdonságaiban. A szemcsék nyújtottsága (azaz a hosszúság/szélesség aránya) szignifikánsan hat a viszkozitásra, ezáltal az anyagrendszer merevségére. Ha a szemcsék nyújtottsága nagy (pl. tüs, pálcikaszerü szemcséknél), a viszkozitás már kis töltőanyag térfogataránynál is nagy lesz. Ezzel szemben a kismértékü nyújtottság (pl. gömbszerü szemcsealak) kis viszkozitást eredményez.

Az aszfaltkeverékek ásványi vázában a töltőanyag frakció fajlagos felületének ismerete fontos. A finomrész mennyiségének növelésével megnő az ásványi anyag fajlagos felülete. Ebből adódóan megnő a bitument adszorbeáló képesség is. Az elterjedten alkalmazott mészkőliszt fajlagos felülete (a Brunauer-Emmett-Teller, BET-módszer szerint) megközelítőleg $1 \mathrm{~m}^{2} / \mathrm{g}$. Amennyiben a finomrész fajlagos felülete túlságosan magas (akár $4-5 \mathrm{~m}^{2} / \mathrm{g}$ ), abban az esetben megnő a bitumenfelvétel, valamint egy optimális mennyiségen túl már csökken a burkolat szilárdsága. Mindezen ismeretek ellenére 
az aszfalttechnológiai gyakorlatban az ásványi anyagok fajlagos felületének meghatározása nem terjedt el.

A fajlagos felület mellett egy másik tulajdonság, az ásványi anyagok belső pórusossága, porozitása is nagy jelentőséggel bír. Minél nagyobb a szemcsék porozitása, annál nagyobb a fajlagos felület, amely egy határon túl negatív hatást eredményez. A túlzottan nagy porozitású ásványi anyagok bitumenfelvétele nemcsak gazdaságilag kedvezőtlen, de az aszfalt gyártását is megnehezíti.

\section{Vizsgálati módszerek bemutatása}

A 2. fejezetben bemutatott rövid áttekintés, helyzetértékelés ismeretében a 2. ábra olyan vizsgálati technikákat foglal össze csoportosítva, amelyek többletinformációt nyújthatnak az aszfaltkeverékek tervezéséhez.

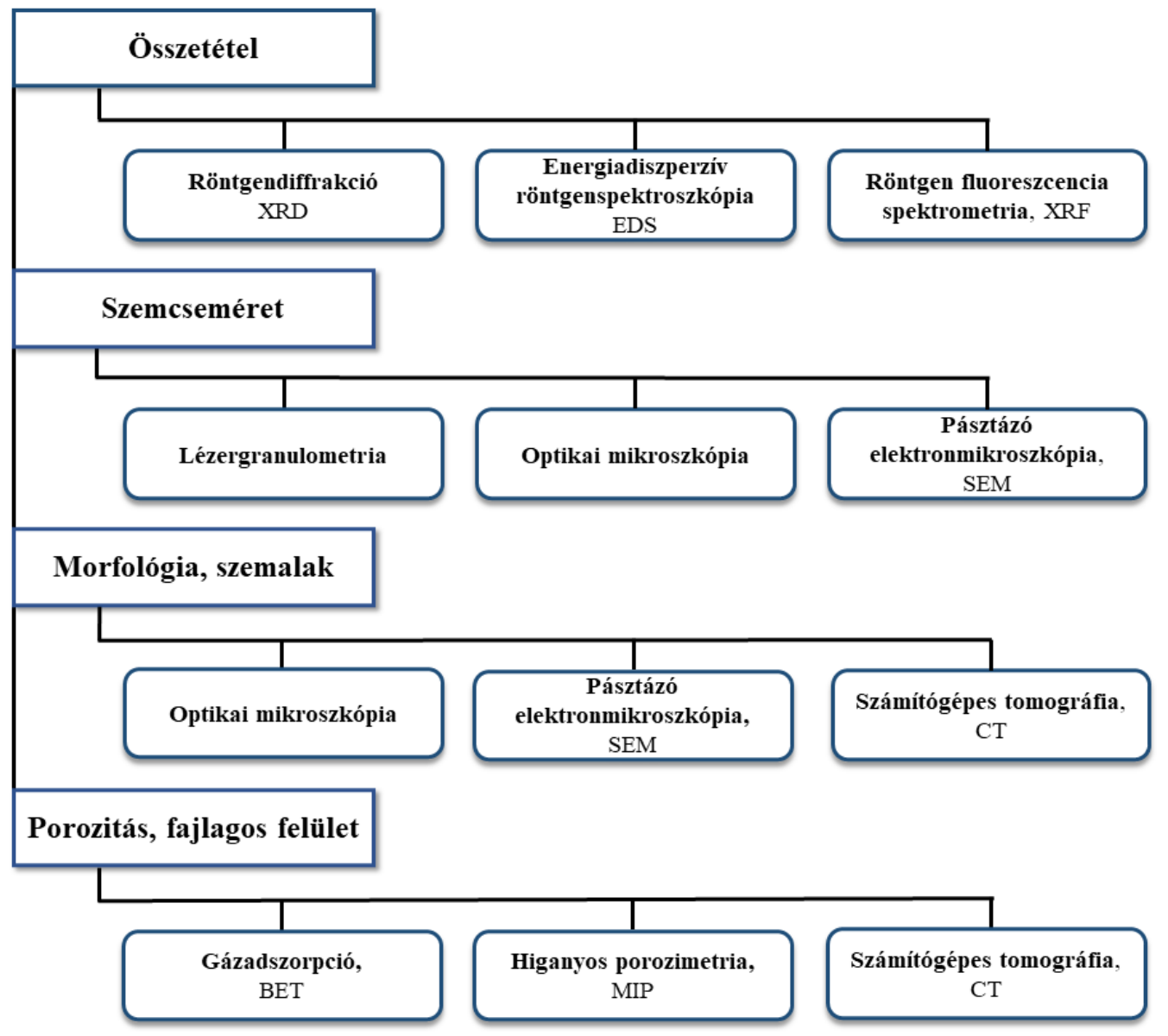

2. ábra. Lehetséges méréstechnikai módszerek ásványi anyagok vizsgálatához.

Az ásványi anyagok összetételének meghatározása több módszerrel is történhet. A legismertebb eljárás a röntgen pordiffrakciós módszer (X-ray diffraction, XRD vizsgálat), melynek során mind minöségi, mind pedig mennyiségi fázisanalízis is elvégezhető. A vizsgálat során a mintát röntgensugárzásnak tesszük ki és detektáljuk a kristályrácsról szóródó sugárzást. A vizsgálat eredményének legelter- 
jedtebb kiértékelési módja a profilillesztéses módszer. Ennek előnye, hogy a röntgensugárzás diffrakciójával kapott intenzitáscsúcsok térbeli helyzetéből és relatív erősségéből meghatározhatóak az ismeretlen anyagok kristályszerkezetei. Végső soron feltárható a kőzeteket alkotó ásványok típusa és mennyisége. A vizsgálat már relatíve kis mennyiségü (néhány gramm) mintával is elvégezhető, melyet elözetesen finom porrá kell örölni [25].

A röntgen fluoreszcencia spektroszkópia (X-ray fluorescence spectroscopy, XRF módszer) alkalmazásakor a létrehozott karakterisztikus röntgensugárzás energiáját használjuk fel az összetétel meghatározásához. A röntgenspektrum csúcsainak energiája jó közelítéssel csak az elem rendszámától függ, ezért az XRF módszer kvantitatív és kvalitatív elemanalitikai célokat egyaránt szolgál. Ugyan a mintaelőkészítés időigényesebb folyamat, a vizsgálat azonban gyors és roncsolásmentes. Alapvetően szilárd minták és vékonyrétegek vizsgálata lehetséges. Mivel a vizsgálat során a szükséges információt a minta felületétől számított néhány mikrométerből nyerjük, ezért az XRF módszert tekinthetjük felületvizsgáló módszernek [26].

Az XRF módszerhez hasonlóan az energiadiszperzív röntgen spektroszkópia (Energy-dispersive Xray spectroscopy, EDX) is elemanalízisre alkalmas méréstechnikai módszer. Jellemzően pásztázó elektronmikroszkópok kiegészítőjeként használható. A módszer alkalmazásakor a vizsgálati mintáról érkező, különböző energiájú röntgenfotonok detektálása történik. A fotonok energiájuk nagysága szerint energiacsatornákba sorolhatók. Végeredményként az energiacsatornák intenzitása eredményezi a vizsgált minta spektrumát. A módszer alkalmazásával vonalmenti, illetve területi elemeloszlás is meghatározható. A minta előkészítése - a későbbiekben bemutatásra kerülő - pásztázó elektronmikroszkóp mintaelőkészítésével megegyezik. Az XRF és EDX módszerek a röntgendiffrakciós vizsgálatok kiértékelését (fázisazonosítást) nagymértékben elősegítik [26].

Ömlesztett anyagok szemcseeloszlásának pontos meghatározásához a lézergranulometria ajánlott. A pontos mérés érdekében folyadék közegben egy zárt rendszerben kell a mintát keringtetni. A mintakamrán átáramló vizsgálati anyagot monokromatikus fénnyel (lézersugár) világítjuk meg, amely a részecskéken többféle szögben szóródik; ezt adott szemcseméret-tartományban müködő detektorokkal érzékeljük. A vizsgálat során ultrahangos kezeléssel és/vagy diszpergálószer alkalmazásával oszlathatók szét az esetlegesen összetapadt szemcsék. A módszer kis mintaigényü, gyors és néhány perc alatt végrehajtható. Különösen alkalmas aszfaltkeverékek töltőanyag frakcióinak vizsgálatára.

A pásztázó (scanning) elektronmikroszkópia (Scanning elctronmicroscopy, SEM) alkalmazásakor elektronnyalábot állítanak elő, melynek felgyorsított elektronjai a mintába csapódnak, majd áthaladnak azon és visszaszóródnak. A mintát elhagyó részecskék detektálhatók. Ezek intenzitásának és energiaeloszlásának a mérésével egyrészt a minta összetételére következtethetünk (EDX vizsgálat), másrészt lehetséges a képalkotás is. A pásztázó elektronmikroszkópok nagyítóképessége széles skálán mozog, konstrukciós kialakítástól függően akár $60 \mathrm{X}-500.000 \mathrm{X}$ nagyítás is elérhető. A mintaelőkészítés szempontjából előnyös, hogy a minta elektromosan vezető legyen, elkerülendő a minta töltődését, így a felvétel torzulását. Ennek érdekében célszerü elvégezni a minta felületének bevonását, amely általában arany, vagy szén rápárologtatásával lehetséges [26]. A vizsgálattal nagy felbontás mellett vizsgálható az ásványi anyag felületi jellege, pórusai, szemalakja.

A computer tomográfiás (Computed tomography, CT) módszer alkalmazásakor a minta röntgensugárral müködő speciális berendezéssel, teljes terjedelmében vizsgálható („felszeletelhető) és térben leképezhető. Ennek a méréstechnikának az a nagy előnye, hogy feltárhatók a belső anyagfolytonossági hibák (pl. pórusok, repedések), valamint kimutathatók a rendszámon alapuló kontrasztkülönbségek is. Emellett megalkotható a minta háromdimenziós modellje, amelyen nagy pontosságú mérés is lehetséges. Olyan roncsolásmentes vizsgálati módszer, melynek során a mintát egy tárgyasztalon elhelyezve 
kis szöggel sorozatosan körbe fordítjuk, miközben minden szögelforduláskor egy röntgenfelvételt készítünk. A minta ellentétes oldalán elhelyezett detektorral rögzítjük a felvételeket. A vizsgálati módszer a morfológia és a szemalak vizsgálata mellett lehetőséget nyújt az ásványi anyagok pórusszerkezetének, pórustérfogatának meghatározására, emellett a bitumen kőzetbe történő beszívódásának jellege is tanulmányozható.

Ömlesztett anyagok fajlagos felületének vizsgálatára elterjedten használt technika a gázadszorpció elvén müködő módszer. A volumetrikus elven müködő fajlagos felületvizsgáló berendezés képes már kis mennyiségü (1-2 gramm) ömlesztett anyag fajlagos felületét is meghatározni. A vizsgálat során az evakuált csőbe helyezett mintát nagyon alacsony hőmérsékletre hütjük. Ezt követően a nyomás növelésével gázzal érintkeztetjük. A nyomás növelésével megnő a minta felületén megkötődött (adszorbeálódott) gázmolekulák száma. Az adszorpció során a gázmolekulák által kialakított réteg vastagsága növekszik. A mért nyomásértékek ismeretében a minta fajlagos felülete (Pl.: BET-féle fajlagos felület) és mikroporozitása (Pl. Barret-Joyner-Halenda, BJH-féle mikroporozitás) is meghatározható. A módszer a töltőanyagok fajlagos felületének meghatározására kifejezetten alkalmas.

A higanyos porozimetria (Mercury intrusion porosimetry, MIP) különböző anyagok pórusrendszerének egyik korszerủ vizsgálati módja, amely lehetővé teszi a szilárd porózus anyagok makro- és mezopórusainak méret- és térfogat meghatározását. Információt nyújt az anyagrendszer belső szerkezetéről, mint például a pórusméret-eloszlásról, a teljes pórustérfogatról (porozitásról), látszólagos sürüségről, valamint a minta fajlagos felületéről. A higanyos porozimetrián kívül jelenleg nincs még egy olyan méréstechnikai elv, amely ugyanezen jellemzők meghatározására egyidejüleg képes. A vizsgálathoz olyan folyadékra van szükség, amely nem lép reakcióba a vizsgálandó anyaggal. A higany, mely egy nemnedvesítő folyadék (azaz a nedvesítési szöge: $\Theta>90^{\circ}$ ), ha érintkezésbe kerül egy szilárd, porózus anyaggal, spontán nem hatol be a porózus anyagba. A pórussugár fordítottan arányos az alkalmazott besajtolási nyomással. Minél nagyobb a vizsgálat során alkalmazott nyomás, annál kisebb pórusokba képes behatolni a higany. A minta által felvett higany mennyisége (térfogata) jellemzi a mintában található pórusok térfogatát. A higanyfelvétel és nyomásváltozás precíz mérésével a pórusok mérete és méreteloszlása is meghatározható. A módszer jól használható nagy porozitású kőanyagok jellemzéséhez.

\section{4. Összefoglalás}

Jelen cikk igyekezett egy rövid áttekintést adni azokról a méréstechnikai módszerekről, amelyek az anyagtudománnyal foglalkozó kutatók körében ugyan közismertek, azonban aszfalttechnológiai alkalmazásukra eddig kevés példa akadt. A Szerző bízik abban, hogy sikerült felkelteni a figyelmet mind az aszfaltgyártók, mind pedig a kőanyag beszállítók körében. A cikkben bemutatott módszerek lehetöséget teremtenek arra, hogy az aszfaltkeverékben felhasznált ásványi anyagok tulajdonságairól pontosabb képet kaphassunk. Ez a többletinformáció az aszfaltkeverékek tervezésénél hasznosulhat a jobb minőségü, hosszabb élettartamú burkolatok előállítása érdekében.

\section{Köszönetnyilvánítás}

A cikkben ismertetett kutató munka az EFOP-3.6.1-16-2016-00011 jelü „Fiatalodó és Megújuló Egyetem - Innovatív Tudásváros - a Miskolci Egyetem intelligens szakosodást szolgáló intézményi fejlesztése" projekt részeként - a Széchenyi 2020 keretében - az Európai Unió támogatásával, az Európai Szociális Alap társfinanszírozásával valósul meg. 


\section{Irodalom}

[1] Wang, L., Liu, H., Zhao, S.: Aggregate gradation design of asphalt mixture with stone-to-stone contact based on Fuller's model, Journal of Shanghai University (English Edition), 14 No. 5. (2010) pp.387-390. https://doi.org/10.1007/s11741-010-0664-3

[2] Chen, J.: Rheological properties of asphalt-mineral filler mastics, Journal of Materials, Concrete Structures and Pavements, 36. No. 571. pp. (1997) 269-277.

[3] Chen, J., Kuo, P., Lin, P., Huang, C., Lin, K.: Experimental and theoretical characterization of the engineering behavior of bitumen mixed with mineral filler, Materials and Structures, 41 (2008) pp. 1015-1024. https://doi.org/10.1617/s11527-007-9302-5

[4] Grabowski, W., Wilanowicz, J.: The structure of mineral fillers and their stiffening properties in filler-bitumen mastics, Materials and Structures, 41. (2008) pp. 793-804. https://doi.org/10.1617/s11527-007-9283-4

[5] Kim, Y. R., Little, D. N.: Linear viscoelastic analysis of asphalt mastics, Journal of Materials in $\begin{array}{llllll}\text { Civil Engineering, } & 16 . & \text { No. } & 2 . & \text { (2004) } & \text { pp.122-132. }\end{array}$ https://doi.org/10.1061/(ASCE)0899-1561(2004)16:2(122)

[6] Ishai, I., Craus, J.: Effects of Some Aggregate and Filler Characteristics on Behavior and Durability of Asphalt Paving Mixtures, Transportation Research Record, 1530. (1996) pp.75-85. https://doi.org/10.3141/1530-10

[7] Loorents, K.-J., Said, S. F.: On mineralogical composition of filler and performance of asphalt concrete, International Journal of Pavement Engineering, 10. No. 4. (2009) pp. 299-309. https://doi.org/10.1080/10298430802169465

[8] Shashidar, N., Chollar, B.H.: Rheological properties of asphalts with particulate additives, American Chemical Society: Division Fuel Chemistry, 41. No. 4. pp. (1996) 1307-1316.

[9] Shashidar, N., Shenoy, A.: On using micromechanical models to describe dynamic mechanical behavior of asphalt mastics; Mechanics of Materials, 34. (2002) pp. 657-669. https://doi.org/10.1016/S0167-6636(02)00166-7

[10] Liao, M.C., Chen, J.S., Tsou, K.W.: Fatigue characteristics of bitumen-filler mastics and asphalt mixtures, Journal of Materials in Civil Engineering, 24. No. 7. (2012) pp. 916-923. https://doi.org/10.1061/(ASCE)MT.1943-5533.0000450

[11] Tóth, Cs., Ureczky, J.: Determination of master curves for asphalt mixtures by means of IT-CY tests, Periodica Polytechnica Civil Engineering, 54. No. 2. (2010) pp. 137-142. https://doi.org/10.3311/pp.ci.2010-2.09

[12] Primusz, P., Péterfalvi, J., Markó, G., Tóth, Cs.: Effect of pavement stiffness on the shape of deflection bowl, Acta Silvatica \& Lignaria Hungarica, 11. No. 1. (2015) pp. 39-54. https://doi.org/10.1515/aslh-2015-0003

[13] Pethö, L., Tóth, Cs.: Long-term pavement performance evaluation, In: Scarpas A., Kringos N., Al-Qadi I., A. L. (eds) $7^{\text {th }}$ RILEM International Conference on Cracking in Pavements. RILEM $\begin{array}{llllll}\text { Bookseries, } & \text { Vol. } & 4 & \text { Springer } & \text { (2012) } & \text { pp. }\end{array}$ https://doi.org/10.1007/978-94-007-4566-7_26

[14] Géber, R., Gömze, L. A.: Characterization of mineral materials as asphalt fillers, Materials $\begin{array}{lllll}\text { Science } & \text { Forum, } & 659 & \text { (2010) } & \text { 471-476. }\end{array}$ https://doi.org/10.4028/www.scientific.net/MSF.659.471

[15] Géber, R, Simon, A., Kocserha I.: Investigation of thermal properties of raw materials of asphalt mixtures, IOP Conference Series: Materials Science and Engineering, 175. No. 1. (2017) https://doi.org/10.1088/1757-899X/175/1/012047 
[16] Géber, R. Kocserha I., Simon, A., Udvardi, B.: Porózus köanyagok anyagszerkezeti vizsgálata, Az Aszfalt, 27. No. 2. (2020), pp. 51-58.

[17] Geber, R, Simon, A., Kocserha, I., Buzimov, A.: Microstructural and rheological analysis of fillers and asphalt mastics, Journal of Physics-Conference Series, 790. (2017) 012009 https://doi.org/10.1088/1742-6596/790/1/012009

[18] Gömze, L. A, Kovács, Á: Aszfaltkeverékek reológiai tulajdonságainak vizsgálata, ÉpítőanyagJSBCM, 57. No. 2. (2005) pp. 34-38. https://doi.org/10.14382/epitoanyag-jsbcm.2005.7

[19] Géber, R.: Mészköliszt és dolomit töltöanyagok hatása aszfalthabarcsok reológiai tulajdonságaira, Útügyi Lapok: A közlekedésépítési szakterület mérnöki és tudományos folyóirata, 1. No. 1. (2013) pp. 1-12.

[20] Géber, R., Apkaryan, S. A., Kulkov, S. N., Gömze, L. A.: Linear viscoelastic properties of asphalt mastics using creep-recovery technique, Materials Science and Engineering: A publication of the University of Miskolc, 39. No. 2 (2014) pp. 5-11.

[21] Soós, Z., Géber, R., Tóth, Cs., Igazvölgyi, Zs., Udvardi, B.: Utilization of aluminium dross as asphalt filler, Építőanyag-JSBCM 69. No. 3. (2017) pp. 89-93. https://doi.org/10.14382/epitoanyag-jsbcm.2017.15

[22] Udvardi, B., Géber, R., Kocserha, I.: Investigation of aluminum dross as a potential asphalt filler, International Journal of Engineering and Management Sciences/ Müszaki és Menedzsment Tudományi Közlemények, 4. No. 1 (2019) pp. 445-451. https://doi.org/10.21791/IJEMS.2019.1.55

[23] Géber, R., Kocserha, I., Ferenczi, T., Kristály, F., Móricz, F., Rácz, Á:. Construction and demolition wastes as potential asphalt fillers, Geosciences and Engineering: A publication of the University of Miskolc, 8. No. 12. (2020) pp. 61-70.

[24] Rawle, A. F.: Rheology and particle size, Malvern Webinar, (2009.02.25.), www.malvern.com

[25] Hegman, N., Pekker, P., Kristály, F., Váczi, T.: Nanometrológia, (2011) Miskolc. ISBN 978963-661-981-7

[26] Zsíros, Gy.: XRF vizsgálatok a gyakorlatban, https://szte.org.hu/upload/3_XRF\%20konf.pdf (letöltés: 2021.01.09.) 